\title{
Remote sensing of aerosols by using polarized, directional and spectral measurements within the A-Train: the PARASOL mission
}

\author{
D. Tanré1 , F. M. Bréon ${ }^{2}$, J. L. Deuzé ${ }^{1}$, O. Dubovik ${ }^{1}$, F. Ducos ${ }^{1}$, P. François ${ }^{1}$, P. Goloub ${ }^{1}$, M. Herman ${ }^{1}$, A. Lifermann ${ }^{3}$, \\ and F. Waquet ${ }^{1}$ \\ ${ }^{1}$ Laboratoire d'Optique Atmosphérique, UMR8518, CNRS-INSU, Université Lille 1, Villeneuve d'Ascq, France \\ ${ }^{2}$ LSCE, CEA, Gif sur Yvette, France \\ ${ }^{3}$ Centre National d'Etudes Spatiales, Toulouse, France
}

Received: 16 March 2011 - Published in Atmos. Meas. Tech. Discuss.: 1 April 2011

Revised: 21 June 2011 - Accepted: 26 June 2011 - Published: 12 July 2011

\begin{abstract}
Instruments dedicated to aerosol monitoring are recently available and the POLDER (POLarization and Directionality of the Earth's Reflectances) instrument on board the PARASOL (Polarization \& Anisotropy of Reflectances for Atmospheric Sciences coupled with Observations from a Lidar) mission is one of them. By measuring the spectral, angular and polarization properties of the radiance at the top of the atmosphere, in coordination with the other A-Train instruments, PARASOL provides the aerosol optical depths (AOD) as well as several optical and microphysical aerosol properties. The instrument, the inversion schemes and the list of aerosol parameters are described. Examples of retrieved aerosol parameters are provided as well as innovative approaches and further inversion techniques.
\end{abstract}

\section{Introduction}

Atmospheric aerosols interact with solar and thermal radiation. By scattering sunlight and reflecting a fraction of it back to space, aerosols first cool the atmosphere-surface system; the resulting effect is named the aerosol direct (or parasol) effect. By absorbing sunlight in the atmosphere, they further cool the surface but warm the atmosphere. As a result, they change the temperature and humidity profiles and the conditions for cloud development; this is the semi-direct effect. They also impact the cloud properties by acting as cloud condensation nuclei and ice nuclei. They modify the

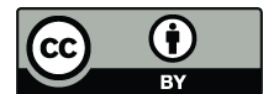

Correspondence to: D. Tanré (didier.tanre@univ-lille1.fr) cloud droplet concentration and tend to decrease the droplet size with potential impact on precipitation, which is named the indirect effects (see, for example, Hansen et al., 1997; Ramanathan et al., 2001).

For estimating the aerosol radiative forcing on the climate, there is a need for discriminating man-made aerosols and those resulting from natural processes. If in situ chemical measurements are required for exact identification, there are other means to retrieve the aerosol origin. For instance, the aerosol size distribution includes several modes that are associated with specific physical or chemical processes. The fine (or accumulation) mode, with effective radius around roughly $0.1-0.2 \mu \mathrm{m}$, is formed from condensation or chemical conversion of gases to the liquid phase. Natural aerosol particles, wind driven sea spray, wind blown dust and soil, fly ash and biogenic particles, are within the coarse mode with radius mainly larger than $1.0 \mu \mathrm{m}$. From satellite, it is clear that anthropogenic aerosols downwind from vegetation fires and industrial pollution regions are characterized by high concentration of fine particles when fine particles emitted by natural process display much smaller spatial variability as confirmed by transport models (Chin et al., 2002). Particle size and spatial distribution can be so used for separating natural from anthropogenic aerosols (Kaufman et al., 2002); the spectral absorption or the non-spherical fraction are also an indication of the aerosol type (see, for example, Kaufman et al., 2002; Dubovik et al., 2002).

To be used in climate models or for evaluating transport models (see, for example, Menon et al., 2002; Chin et al., 2002), the knowledge of the aerosol distribution is required at a global scale on a daily basis with a resolution of $1-10 \mathrm{~km}$, which can be only achieved using remote sensing from

Published by Copernicus Publications on behalf of the European Geosciences Union. 
sun-synchronous satellites. The A-Train satellite formation (http://aqua.nasa.gov/doc/pubs/A-Train_Fact_sheet.pdf), which consists of presently five satellites flying in constellation, has been so designed to study aerosol (Anderson et al., 2005), clouds and precipitation; in addition to the CALIOP (Cloud-Aerosol Lidar with Orthogonal Polarization) lidar, the instruments specifically dedicated to aerosol monitoring using the sunlight reflected by the Earth, are PARASOL/POLDER and AQUA/MODIS (MODerate resolution Imaging Spectrometer).

This paper provides a description of the PARASOL mission with a brief summary of the instrument, the list of the retrieved aerosol parameters illustrated with few examples. Finally, enhancements expected by the use of more sophisticated inversion schemes are given.

\section{The PARASOL mission}

In the 60's and 70's, polarization measurements were performed on planets such as Venus. They have been shown powerful for deriving informations on the clouds formed principally of an aerosol of sulphuric acid (Dollfus and Coffee, 1970; Hansen and Hovenier, 1974; Santer and Herman, 1979). Similar measurements were then considered for observing earth atmosphere. It was made clear that the angular information was crucial (e.g. Herman et al., 1986; Herman and Vanderbilt, 1997; Mishchenko and Travis, 1997) and early measurements were achieved from balloon or aircrafts (Herman et al., 1986; Deuzé et al., 1993; Chowdhary et al., 2001). The corresponding instruments are the precursors of present satellite sensors like POLDER on ADEOS (Deschamps et al., 1994) and APS on GLORY (Mishchenko et al., 2007). Unfortunately, due to failure of the ADEOSI (Advanced Earth Observing System) and ADEOS-II solar panels, the POLDER measurement time series were limited to respectively 8 and 7 months in 1996-1997 and 2003 respectively.

PARASOL is the second in the Myriade line of microsatellites developed by CNES, the French Space Agency. The platform was launched in December 2004 in order to be part of the A-Train and has a sunsynchronous orbit with 1:30 p.m. ascending node at an altitude of $705 \mathrm{~km}$. The mission takes advantage of the other instruments in the constellation, which for our objectives mainly include MODIS (King et al., 1992) on the AQUA satellite (Parkinson, 2003) and CALIOP on CALIPSO (Cloud-Aerosol Lidar and Infrared Pathfinder Satellite Observation) (Winker et al., 2003, 2009, 2010). From MODIS, the aerosol characteristics are derived at the $10 \times 10 \mathrm{~km}^{2}$ resolution over the ocean (Tanré et al., 1997) and land (Kaufman et al., 1997) using independent algorithms (Remer et al., 2005). For CALIOP, algorithms have been developped to classify aerosol layers and to evaluate the AOD (Omar et al., 2005; Vaughan et al., 2009). Let us mention that although the TERRA/MISR (Multi-angle Imaging Spectro-Radiometer) instrument is not part of the train and cannot be used in synergy with PARASOL, it has also angular capabilities such as POLDER for deriving the AOD and aerosol type (Kahn et al., 2001).

The PARASOL payload consists of a digital camera with a 274× 242-pixel CCD detector array, wide-field telecentric optics and a rotating filter wheel enabling measurements in 9 spectral channels from blue $(0.443 \mu \mathrm{m})$ through to nearinfrared $(1.020 \mu \mathrm{m})$. Polarization measurements are performed at $0.490 \mu \mathrm{m}, 0.670 \mu \mathrm{m}$ and $0.865 \mu \mathrm{m}$. The bandwith is between $20 \mathrm{~nm}$ and $40 \mathrm{~nm}$ depending on the spectral bands. The pixel size is $5.3 \mathrm{~km} \times 6.2 \mathrm{~km}$ at nadir. Because it acquires a sequence of images every $20 \mathrm{~s}$, the instrument can observe ground targets from different view directions, $+/-51^{\circ}$ along track and $+/-43^{\circ}$ across track. Considering the altitude of the constellation ( $705 \mathrm{~km})$, the size of the images is of $2100 \times 1600 \mathrm{~km}^{2}$ which results in a global coverage within two days. Compared to POLDER-I and II, the telecentric optics array has been turned 90 degrees to favour multidirectional viewing (maximum of 16 directions compared to 14) over daily global coverage. Likewise, a $1020 \mathrm{~nm}$ waveband has been added to conduct observations for comparison with data acquired by the CALIOP lidar at $1064 \mathrm{~nm}$ on CALIPSO. PARASOL also relies on the innovative techniques (Hagolle et al., 1999) developed to calibrate in-flight the POLDER instruments. The method uses in particular molecular scattering, the Sun's reflection from the ocean surface, clouds and desert areas as targets to validate the pre-flight performance (Fougnie et al., 2007). The temporal degradation of the sensor is monitored and corrected for in real time (Fougnie and Bach, 2009).

\section{The PARASOL data processing and the derived aerosol parameters}

The parameters that are usually accessible from remote sensing are (i) the aerosol optical depth (AOD), that is a measure of the integrated aerosol load through the atmosphere valuable for evaluating aerosol amount and (ii) the Ångström Exponent (AE) related to the spectral dependence of AOD that gives an indication of the column integrated aerosol size distribution. With the polarized and directional signatures, in addition to the commonly spectral signature, POLDER data are better suited to select the aerosol model in the inversion algorithm and to determine the size and shape of particles over the ocean. Over land for highly reflective surfaces, only polarization data are presently used. Our land retrieval scheme is based on the following findings: (i) the surface polarized reflectances are rather uniform and constant, (ii) the atmospheric contribution is larger than the surface polarized reflectance. Nevertheless, since polarization is mainly controlled by small particles, only the small (or accumulation) mode can be retrieved. This existing limitation will be overcome with the more sophisticated inversion scheme under development (Dubovik et al., 2011). 


\subsection{The algorithms}

Algorithms have been developed to process the POLDER measurements in terms of aerosols parameters (Table 1) provided at $18.5 \times 18.5 \mathrm{~km}^{2}$ resolution $(3 \times 3$ pixels $)$. Computations of the Look-Up Tables (LUT) are based on the planeparallel assumption and use the successive orders of scattering method (Lenoble et al., 2007).

Over the ocean where the surface is dark in the red and near infra-red spectral regions, several aerosol parameters are derived using the inversion scheme developped by Deuzé et al. (1999) and Herman et al. (2005). The ocean reflectance is modelled with the Cox and Munk (1954) equations assuming a wind speed of $5 \mathrm{~m} \mathrm{~s}^{-1}$ for considering the surfaceatmosphere multiple interactions. The actual wind speed provided by the ECMWF weather forecast model is used in the glint mask and for computing the foam reflectance according to the Koepke's model (1984); the underwater contribution is taken equal to 0.001 and 0.000 at 670 and $865 \mathrm{~nm}$ respectively. The algorithm uses the total and polarized radiances at 670 and $865 \mathrm{~nm}$ and assumes that the size distribution follows a combination of two lognormal aerosol size distributions, one in the fine or accumulation mode (sub-micron size, effective radius $r_{\text {eff }}$ typically smaller than $0.5 \mu \mathrm{m}$ ) and one in the coarse mode ( $r_{\text {eff }}$ typically larger than $\left.1.0 \mu \mathrm{m}\right)$. Nonabsorbing particles are considered in both modes. The total radiance, $L$, at the satellite level is written,

$$
L\left(\mu_{\mathrm{s}}, \mu_{\mathrm{v}}, \phi_{\mathrm{v}}\right)=\eta L^{\mathrm{f}}\left(\mu_{\mathrm{s}}, \mu_{\mathrm{v}}, \phi_{\mathrm{v}}\right)+(1-\eta) L^{\mathrm{c}}\left(\mu_{\mathrm{s}}, \mu_{\mathrm{v}}, \phi_{\mathrm{v}}\right)
$$

where $\eta$ is the radiance weighting factor (which is also the ratio between fine mode and total optical thickness), $L^{\mathrm{f}}\left(\mu_{\mathrm{s}}\right.$, $\left.\mu_{\mathrm{V}}, \phi_{\mathrm{V}}\right)$ and $L^{\mathrm{c}}\left(\mu_{\mathrm{s}}, \mu_{\mathrm{v}}, \phi_{\mathrm{V}}\right)$ the radiances of the fine (f) and coarse (c) modes respectively, $\mu_{\mathrm{S}}=\cos \left(\Theta_{\mathrm{s}}\right)$ with $\Theta_{\mathrm{s}}$ the solar zenith angle, $\mu_{\mathrm{v}}=\cos \left(\Theta_{\mathrm{v}}\right)$ for the viewing zenith angle, and $\phi_{\mathrm{v}}$ the relative azimuth angle. Equation (1) (Wang and Gordon, 1994) assumes that the effect of the multiple scattering on the spectral radiance is independent on the size distribution. The retrieved parameters are reported in Table 1. In the coarse mode, spherical or non-spherical particles (as needed for saharan dust, see Volten et al., 2001) are considered and when the geometrical conditions are optimal (scattering angle range of roughly $90^{\circ}-160^{\circ}$ ), the shape of the particles is derived (Herman et al., 2005). The refractive index retrieval is attempted from the polarization measurements. Whereas the real part of the refractive index of the coarse mode is retrieved when spherical particles are present (generally close to 1.35 , indicating hydrated particles), the derivation of the refractive index of the accumulation mode is still tentative. It should be also noted that PARASOL has at least one viewing direction out of the glint making aerosol AOD retrievals possible everywhere over water.

Over land surfaces, the PARASOL aerosol retrieval is based on polarized measurements $L^{\mathrm{POL}}\left(\mu_{\mathrm{s}}, \mu_{\mathrm{v}}, \phi_{\mathrm{v}}\right)$ at 670 and $865 \mathrm{~nm}$ (Herman et al., 1997b; Deuzé et al., 2001). Contrary to the total radiances, polarized reflectance of surfaces is small and fairly spectrally independent (Nadal and Bréon, 1999; Maignan et al., 2009). Scattering by the spherical particles within the accumulation mode (radii less than about $0.5 \mu \mathrm{m})$ generates highly polarized light, which makes the polarized satellite radiances more subject to the presence of aerosols than the total radiances. So, the models used in the land algorithm are considering aerosols within the accumulation mode only and the contribution of the coarse mode is neglected (see Table 1). The refractive index is taken equal to $1.47-0.01$ which corresponds to a mean value for aerosols resulting from biomass burning or pollution events (Dubovik et al., 2002). The surface contribution depends on the surface type, bare soils or vegetated areas and is estimated from a relationship using empirical coefficients adjusted for the different classes of land surfaces according to the main IGBP (International Geosphere-Biosphere Programme) biotypes and the NDVI. Although larger aerosol particles, such as desert dust, almost do not polarize sunlight and are therefore hardly detected from polarization measurements, the coarse mode can contribute to the polarization for very intense events and may lead to misinterpretation of the retrieved AOD.

The aerosol size distribution and refractive indices that are used in both cases, land and ocean, are reported in the Appendix.

\subsection{Validation}

As mentionned, the AOD derived from space needs validation with ground truth data. There are several international networks that have extensive records of AOD measurements like AERONET (AErosol RObotic NETwork; Holben et al., 1998), BSRN (Baseline Surface Radiation Network; WMO, 1991), GAW-PFR (Global Atmosphere Watch - Precision Filter Radiometer; GAW, 2004), and SKYNET (Atmospheric radiation and weather observation network in Japan; http://atmos.cr.chiba-u.ac.jp/) but the long period of observations and the multi-site aspect of AERONET with around 200 sunphotometers distributed around the world (Holben et al., 2001) make it very attractive as a validation tool.

Total AOD's are derived from POLDER over ocean only. So, comparisons with ground based measurements require to use the coastal AERONET sites with the assumption that the aerosol layer is uniform over few kilometers. Previous comparisons between AERONET and POLDER-1 on ADEOS showed good agreement with typical RMS errors on the order of 0.05 with no significant bias (Goloub et al., 1999). For POLDER/PARASOL, Bréon et al. (2011) showed also a good correlation (0.91) but with a bias of around 0.03 . Let us point out that mis-calibration of the satellite sensor would result in a systematic bias but, based on our calibration error budget (Fougnie et al., 2007), it cannot explain the 0.03 value. Residual straylight may explain the biais and specific studies are under way. 
Table 1. List of the aerosol parameters currently derived from the PARASOL operational algorithms: over ocean $\left(\tau_{\text {tot }}=\right.$ total aerosol optical depth; $r_{\text {eff }}=$ effective radius of the aerosol size distribution; $m_{\mathrm{r}}=$ real part of the refractive index of the aerosol fine mode; $\alpha=$ Angstrom exponent for total aerosol optical depth; $\tau_{\mathrm{acc}}=$ optical depth of the aerosol fine mode; $\tau_{\mathrm{c}, \mathrm{ns}}=$ optical depth for large nonspherical aerosols) and over land $\left(\tau_{\text {acc, land }}=\right.$ optical depth of the aerosol fine mode). The spatial resolution is $18.5 \times 18.5 \mathrm{~km}^{2}$ and the parameters are vertically integrated. Accuracy of some parameters is still to assess (TBD).

\begin{tabular}{llll}
\hline $\begin{array}{l}\text { Retrieved } \\
\text { quantity }\end{array}$ & $\begin{array}{l}\text { Typical } \\
\text { accuracy }\end{array}$ & $\begin{array}{l}\text { Retrieval algorithm } \\
\text { reference }\end{array}$ & $\begin{array}{l}\text { Validation } \\
\text { reference }\end{array}$ \\
\hline$\tau_{\text {tot }}$ & $\begin{array}{l} \pm 0.05 \tau \pm 0.05 \\
\text { Fine: } 0.05 \mu \mathrm{m}\end{array}$ & $\begin{array}{l}\text { Deuzé et al. (1999) } \\
\text { Herman et al. (2005) }\end{array}$ & Goloub et al. (1999) \\
& Coarse: $0.5 \mu \mathrm{m}$ & & \\
$m_{\mathrm{r}}$ & 0.10 & Herman et al. (2005) & - \\
$\alpha$ & $0.3-0.5$ & Deuzé et al. (1999) & Goloub et al. (1999) \\
$\tau_{\text {acc }}$ & TBD & Herman et al. (2005) & Bréon et al. (2010) \\
$\tau_{\mathrm{c}, \mathrm{ns}}$ & TBD & Herman et al. (2005) & - \\
$\tau_{\text {acc, land }}$ & TBD & Deuzé et al. (2001) & Fan et al. (2008) \\
\hline
\end{tabular}

The fine-mode optical depth can also be compared to AERONET measurements. Over ocean, the accuracy is generally lower (correlation of 0.78) than for the total AOD (Bréon et al., 2011) partly due to some discrepancy in the aerosol radius cutoff value. In the corresponding study, it is the standard value of AERONET cutoff $(r \leq 0.6 \mu \mathrm{m})$ which is used whereas POLDER sensivity is expected to be around 0.3-0.4 $\mu \mathrm{m}$. Over land, Bréon et al. (2011) get a significant correlation $(0.84)$ with the sunphotometer measurements. Again, the value of the cutoff can lead to an underestimation of the satellite retrieval compared to AERONET. Over land and in regions where dust-loaded atmospheres are excluded, i.e. in regions affected by biomass burning or pollution aerosols, comparisons with AERONET measurements show better results with no significant bias. A specific study (Fan et al., 2008) comparing AERONET data over Beijing and Xianghe in China demonstrated the capability of PARASOL for determining the anthropogenic contribution (particle radii less than or equal to $0.3 \mu \mathrm{m}$ ) of regional aerosols. Correlation between the two data sets gives a slope close to one and a 0.03 RMS on AOD when the contribution of the accumulation mode to the AOD at $865 \mathrm{~nm}$ is larger than $30 \%$.

Angström exponents $\alpha$ over ocean were also compared in Goloub et al. (1999). When comparisons are restricted to an aerosol optical depth larger than 0.1 at $865 \mathrm{~nm}$, the PARASOL $\alpha$ values allow the differentiation of the aerosol types.

\subsection{Discussion}

When data set are limited to the "best observation conditions", i.e. spatial and temporal variations of the aerosol field discarded and consistency of the aerosol type over the time checked, both AERONET and PARASOL AOD's are in good agreement. It confirms that the assumptions (aerosol models of the LUT's, surface effects) used in the inversion algorithm itself are valid, as well as the forward computations.
There are several factors to explain the discrepancies between AERONET and PARASOL that are observed when more comprehensive data sets are considered. Cloud screening may be more or less stringent and comparison of the operational products may be affected. For POLDER, the cloud screening (Bréon and Colzy, 1999) is based on thresholds on the total and polarized reflectances in different spectral bands, on the detection of the polarized rainbow corresponding to the presence of water droplets and on the spatial variability of reflectance (over ocean) and the pressure derived within the $\mathrm{O}_{2}$ absorption band at $762 \mathrm{~nm}$ (over land). Based on on-going additional analysis using the CALIOP information, there are some thin cirrus that are not detected by the cloud screening and bias the aerosol products. We so far do not identify clever solutions to improve it with the present spectral coverage.

Retrieval accuracies of the AOD's are also depending on the underlying surface,. The sensitivity to the presence of aerosol has a minimum at the critical surface albedo, that is depending on the aerosol single scattering albedo (Fraser and Kaufman, 1985). When the surface is bright, the aerosol retrieval requires more sophisticated approaches than over ocean since the sensitivity to the presence of aerosol decreases. The properties of the initial aerosol models are also more crucial over reflecting surfaces than over ocean ; for instance the impact of the aerosol single scattering albedo is larger over bright surfaces. The impact of some external factors is also larger : cloud screening is more challenging over land and the uniformity of the aerosol field is more questionable close to the sources. In the case of PARASOL/POLDER over land, the AOD is resulting for the fine mode and is more challenging to validate since information on the aerosol size distribution is therefore needed. Over ocean, the problem is not so ill-conditioned but there are other issues. For instance, in presence of non-spherical particles, the spectral dependence of the radiance, that controls the size retrieval, 
is more similar to that of particles smaller than those really present. So the choice, and the number, of aerosol models used to build the Look-Up-Tables are crucial and impact the AOD and size retrievals.

The PARASOL archive is now large enough with $6 \mathrm{yr}$ of data to perform regional studies for assessing the inversion performances in different regions and for different atmospheric conditions.

\section{Retrieval results}

PARASOL offers the unique capability of measuring spectral and angular polarization, which yields additional insight into aerosol optical properties beyond aerosol optical thickness and Angström exponent. As it is demonstrated in Dubovik et al. (2011), additional aerosol properties including information about absorption and composition (refractive index) are expected to be derived from PARASOL. Meanwhile, the unique capabilities of the sensor are hereinafter illustrated by the two following aerosol parameters: (i) the AOD due to non-spherical particles over ocean and (ii) the AOD of the accumulation mode available over land and ocean.

\subsection{Non-Spherical aerosols over the ocean}

The optical depths of the non-spherical coarse mode over the ocean are averaged over the seasons of the five and a half years of data presently available. On Fig. 1, rows represent the AOD for the four seasons of a given year, winter (DJF), spring (MAM), summer (JJA) and autumn (SON) from the left to the right respectively, starting in spring 2005 and ending in summer 2010. Figure 1 shows that non-spherical particles is a major component of the aerosols over the ocean. It is associated essentially to the presence of mineral dust since sea-salt aerosols are expected to be spherical due to their hygroscopic nature when the ambient relative humidity is high (Chamaillard et al., 2003), which is the case in average maritime air conditions. Let us point out that our analysis is not biased by the presence of other aerosol types like smoke in the winter from the Sahel over the Golf of Guinea or in the summer from the South-Western African region since fine or large spherical particles are excluded.

Over the Atlantic ocean, we observe the well-known general patterns of spatial and temporal distributions of Saharan Dust outbreaks (Husar et al., 1997; Prospero et al., 2002; Washington et al., 2003; Kaufman et al., 2005). In winter time (left column), dust is transported over the Gulf of Guinea and is reaching the coast of Brazil in South America. The inter-annual variability can also be observed with low contents in 2006 and 2010 when 2007, 2008 and 2009 are dustier. Again, our results are not biased by the possible presence of smoke in the area. In the summer (3rd column from the left), since the latitudinal variation is controlled by the movement of the West African mid-tropospheric jet (Carlson and Prospero, 1972), the dust belt is in its northern most position $\left(20^{\circ} \mathrm{N}\right)$ and reaches the Caribbean islands and Florida with large year-to-year variations. In the autumn (right column), most of the Atlantic Ocean is free of aerosols with the presence of dust limited to areas close to the African continent. Dust is also transported across the Atlantic Ocean to the Amazon Basin in spring (2nd column) but northwards and with higher concentrations. For the Arabia sea and the Bay of Bengal, the seasonnal variation is similar to that for the Atlantic ocean with smaller contents and a larger extent in 2008 and 2009 compared to the other years. Over the Pacific Ocean, AOD coming from non-spherical particles has a seasonnal variability with a maximum occuring in the spring. It corresponds to the seasonal cycle of dust storm activity in Asia (Middleton, 1991; Prospero et al., 2002; Washington et al., 2003). It is also consistent with westerly flows observed in the region. Due to atmospheric circulation, dust plumes can be transported over long distances and reach the West Coast of the United States. Let us notice that the northern part of the west pacific is more affected by dust that the southern part. The seasonnal variation of pollution aerosol transport presents some similarities (Yu et al., 2008) and dust can be mixed with other aerosol types. The PARASOL capability to discriminate spherical and non-spherical particles is so very valuable in this region.

\subsection{Aerosol optical depth anomaly of the accumulation mode over land and ocean for the autumn (September-October-November).}

Aerosol optical depth anomalies for the $5 \mathrm{yr}$ are compared with the 2005-2009 mean values in Fig. 2. We selected the autumn season when the number of fires is expected to be maximum in the tropical regions. As pointed out in Fig. $2 \mathrm{f}$ (bottom right), high values of the AOD are reported over Brazil, South Africa and Indonesia; high values not related to Biomass Burning are also observed in the north part of India and East of China. Figure 2a to e show the interannual variations over the $5 \mathrm{yr}$ from September 2005 to November 2009 respectively.

Lower concentrations are reported over Africa in 2006 as well as over South America and Indonesia in 2008 and 2009. On the other hand, large concentrations are observed in Indonesia in 2006 and over Brazil in 2007 and to a less extend in 2005. Our results are in good agreement with other studies using MODIS (Remer et al., 2008) or more recently using OMI (Ozone Measuring Instrument) (Torres et al., 2010).

The causes of these fluctuations are multiple: (i) changes in intensity and number of fires or controls of pollutant emissions, (ii) changes in meteorological fields that affect aerosol transport or (iii) changes in scavenging processes, precipitations or dry deposition. Compared to OMI or/and MODIS, PARASOL selects the aerosol fine mode resulting from anthropogenic activities and is sensitive equally to pollution events and smoke. The puzzle can be solved by using inverse 


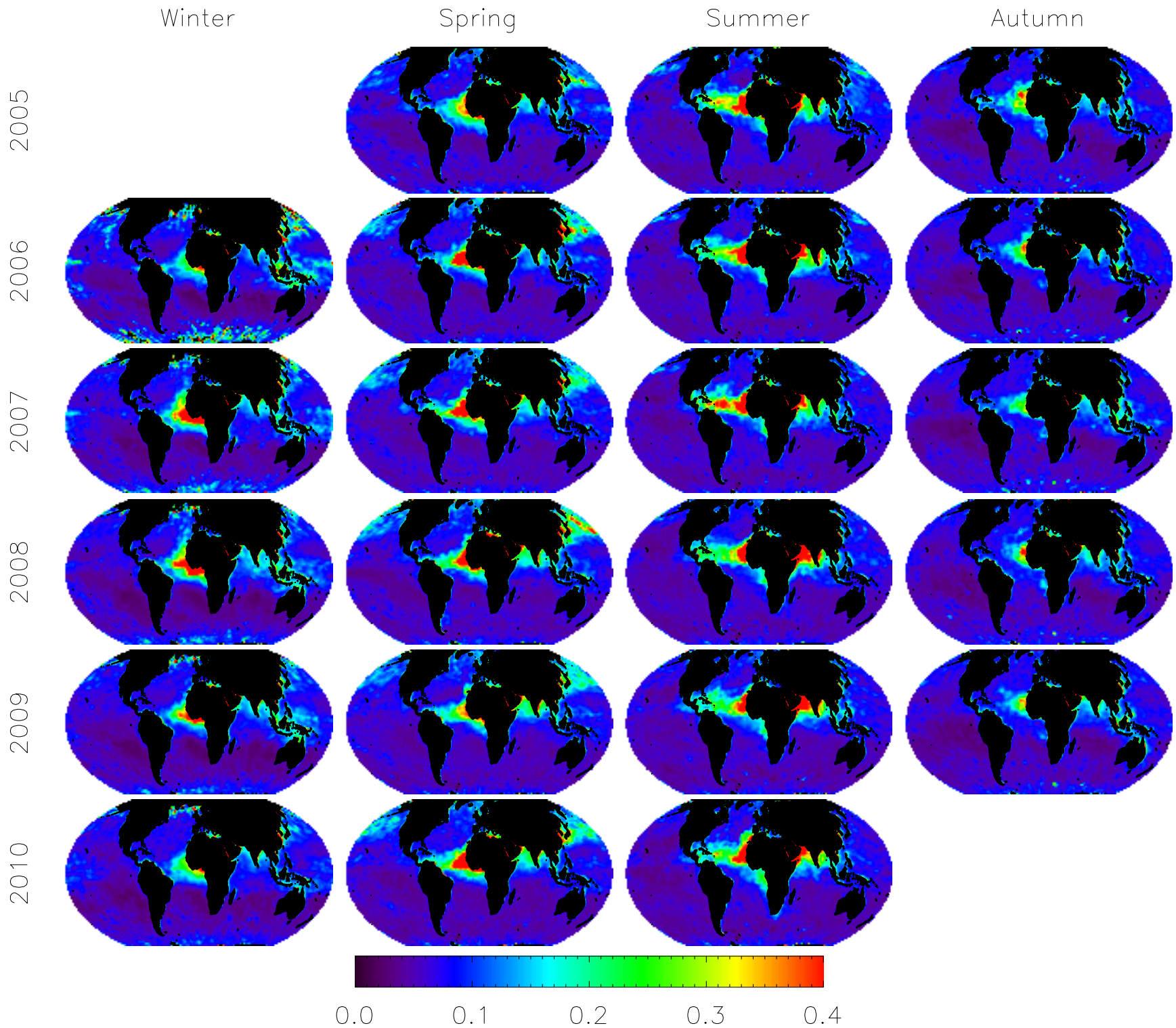

Fig. 1. AOD at $550 \mathrm{~nm}$ resulting from the non-spherical coarse mode. Seasons are ordered from the left to the right (winter, spring, summer, autumn, respectively); years from the top to the bottom (from 2005 to 2010).

modeling to retrieve the global aerosol source emissions as explained in Dubovik et al. (2008).

\section{Further developments}

The PARASOL measurements are sensitive to several parameters of the aerosol model: the size distribution, the real and imaginary parts of the refractive index, the particle shape, and the altitude of the aerosol layer (see e.g. Deuzé et al., 2001; Herman et al., 2005; Mishchenko et al., 2007; Chowdhary et al., 2001; Hasekamp, 2010). The algorithms, as described in Sect. 3, are not sophisticated enough for considering all the variables at once. In this section, we first illustrate the potentiality of the PARASOL data for discriminating absorption and altitude of the aerosol layer using both the total and polarized radiances. Then, a short description of the upcoming algorithms is provided. Finally, the unique capability of passive sensors like PARASOL to detect the presence of an aerosol layer above a cloud deck and to estimate its AOD, as described in Waquet et al. (2009), is pointed out.

\subsection{Altitude/absorption}

Over land, in the UV, most of the earth surfaces are dark and the spectral ratio of radiances, called the Aerosol Index "AI", in two UV channels of the TOMS (Total Ozone Mapping Spectrometer)/OMI series instruments were found to 


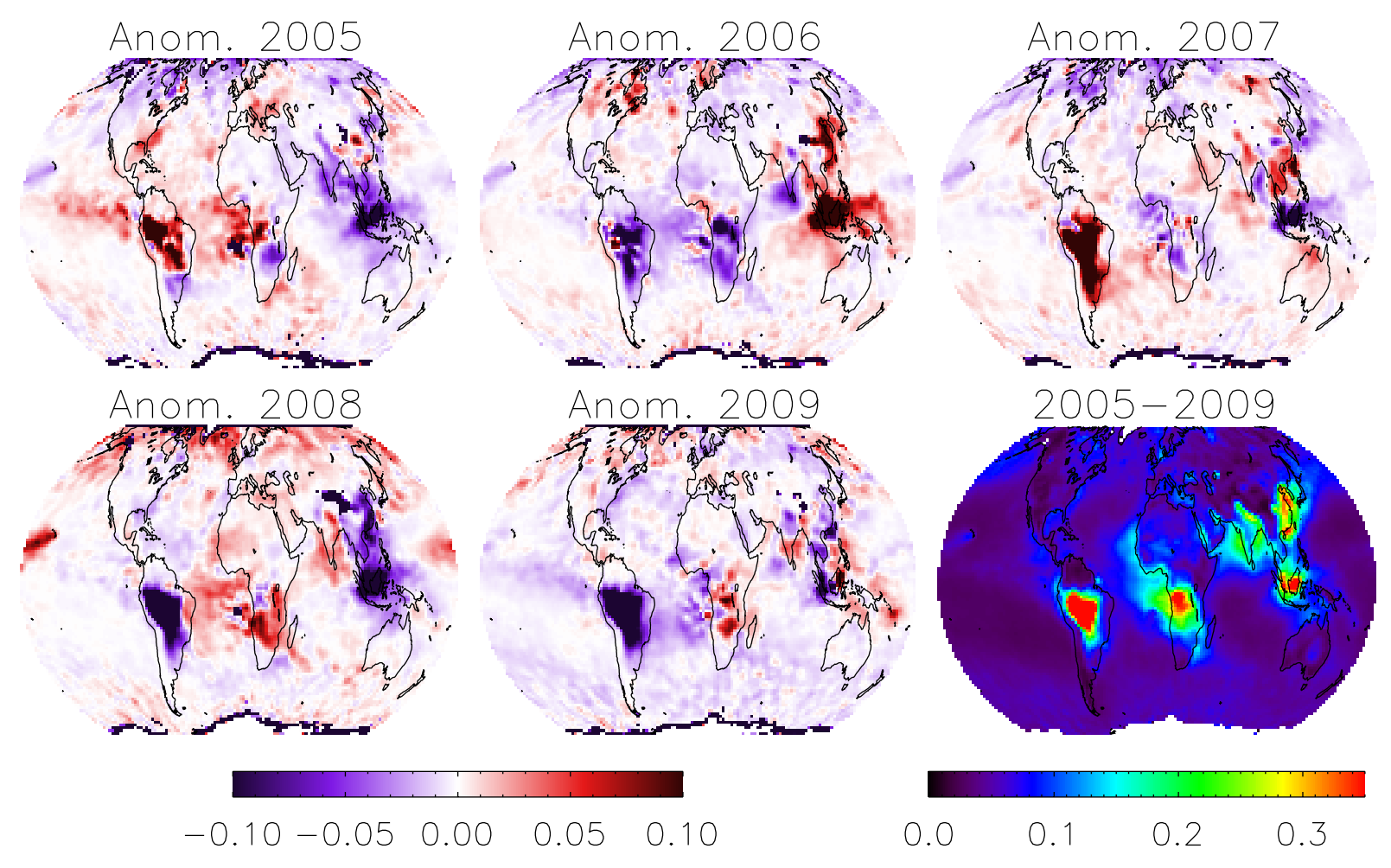

Fig. 2. AOD at $550 \mathrm{~nm}$ resulting from the accumulation mode averaged over three months September-October-November and the $5 \mathrm{yr}$ (bottom right). (a) to (e) AOD anomalies for the $5 \mathrm{yr}$ from 2005 to 2009 respectively. Blues indicate that the AOD of the year was lower than the long term mean and reds indicate higher values.

be sensitive to the presence of elevated or absorbing aerosol layers (i.e. smoke or dust) above scattering atmosphere (Herman et al., 1997a). The use of AI is widespread since it is a satellite product that provides aerosol information at a global scale (and over deserts) over a large period of time. CALIPSO and MISR are also attractive but their daily spatial coverage is more limited. In a similar way, it was suggested to use the bluest channel of MODIS (Hsu et al., 2006) for solving the surface contamination over surfaces reflecting in the visible. Nevertheless, the analysis in terms of aerosol content is not obvious since the altitude and the absorption of the aerosol layer are both impacting the AI. We hereinafter illustrate the improvements brought by PARASOL by using polarization measurements at $0.490 \mu \mathrm{m}$ in connection with total radiances.

The present aerosol algorithm over land is based on a best fit between polarized measurements at $0.670 \mu \mathrm{m}$ and $0.865 \mu \mathrm{m}$ and LUTs simulated for aerosols within the accumulation mode (see section 3.1 and Appendix). In the algorithm, aerosols and molecules are vertically distributed with height scales of 2 and $8 \mathrm{~km}$ respectively and one value of the aerosol absorption is considered. If the vertical repartition has no strong impact on polarized reflectances in the $0.670 \mu \mathrm{m}$ and $0.865 \mu \mathrm{m}$ spectal bands where the molecular optical depth is low (respectively 0.043 and 0.016 ), it is not true in the blue channel at $0.490 \mu \mathrm{m}$. Likewise, the total radiances in the blue are impacted by aerosol absorption and to a less extend by the aerosol vertical repartition.

Figure 3 shows that the problem is actually rather one well-posed problem as soon as polarization measurements are considered. For standard observations, scattering angle of $102^{\circ}$ and an aerosol effective radius of $0.2 \mu \mathrm{m}$, we consider several aerosol vertical repartitions and different values of the imaginary part of the refractive index, from $5.010^{-3}$ to $3.010^{-2}$ which correspond to a single scattering albedo between 0.974 and 0.860 respectively. The aerosol layer is supposed to follow a rectangular step function of $1 \mathrm{~km}$ width and is identifed by the value of half-maximum, $0.5 \mathrm{~km}, 1.5 \mathrm{~km}$, etc. Three AOD's are considered, 0.0, 0.5 and 1.0. Doublelines represent the total radiances that would be measured for one value of the absorption and different altitude layers, solid lines the polarized radiances that would be measured for one value of the altitude layer and different absorptions. If both radiances are impacted by the two unknowns, it is the absorption that is the driving parameter for the radiances (doublelines are almost parallel to the $y$-axis) and the altitude for the polarized radiances (solid lines are almost parallel to the $\mathrm{x}$ axis). The polarized radiances result from photons that are scattered once or two times, so absorption has a limited impact but the respective location of molecules and aerosols is 


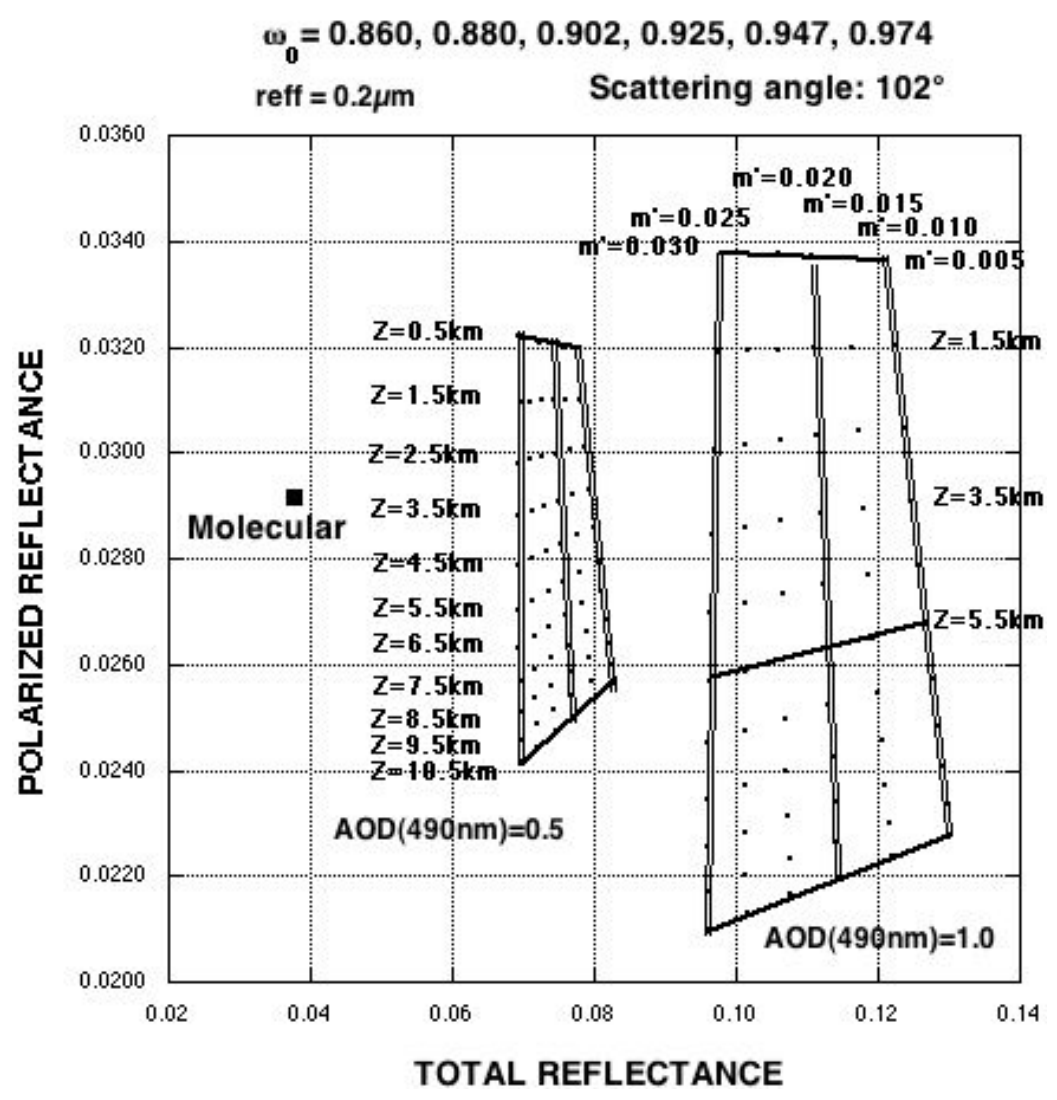

Fig. 3. Scatter plot of the total and polarized reflectance for a number of radiative transfert simulations involving aerosols layers of different optical depth $[0,0.5,1]$, altitude [0.5 to $10.5 \mathrm{~km}$ by step of $1 \mathrm{~km}]$ and absorption (quantified by the imaginary part of the refractive index: 0.005 to 0.03 by step of 0.005 ). The optical depth of 0 corresponds to a pure molecular atmosphere and is shown as a reference. For the two other aerosol optical depths, the single solide lines show the reflectance/polarized reflectance trajectories for constant layer altitude, while the double lines are the same for a constant refractive index. Observation geometry is for a scattering angle of $102^{\circ}$, and the aerosol model has a fine mode effective radius of $0.2 \mu \mathrm{m}$.

important since the aerosol layer is "hiding" the molecular contribution coming from below. On the other hand, due to multiple scatterings, the total radiances are more depending on absorption when AOD is large enough with a limited impact of the vertical repartition except for grazing incidence or view direction. As a result, assuming that the aerosol model as well as the spectral dependence are estimated from measurements at $0.670 \mu \mathrm{m}$ and $0.865 \mu \mathrm{m}$, the PARASOL polarized and total radiances in the blue can deconvolve the relative influences of altitude and absorption. Obviously, the sensitivity of both polarized and total radiances to the absorption and altitude decreases strongly with the AOD.

This mask effect of molecular scattering by aerosols is an example of the basic physical process behind our statement that the PARASOL observations present sensitivity to several aerosol parameters that are not accessible from unpolarized sensors.

\subsection{Enhanced retrieval of aerosol properties}

The PARASOL observations form the most comprehensive data set (spectral, directional and polarized radiances) currently available from space and provide an opportunity for more in-depth use of statistical optimization principles in satellite data inversion. As reported in Dubovik et al. (2011), the statistical optimization principles concept improves retrieval accuracy relying on pronounced data redundancy (excess of the measurements number over number of unknowns) that is not common in satellites observations.

As illustrated in Kokhanovsky et al. (2010) from synthetic data, the PARASOL-like measurements associated with the new sophisticated inversion algorithm (Dubovik, 2004; Dubovik et al., 2011) are the most accurate means for retrieving the properties of the aerosol model (a maritime aerosol model over a black surface in the corresponding study) when compared with other algorithms developped for different sensors in a blind-test. The new method addresses important aspects of inversion optimization as accounting 


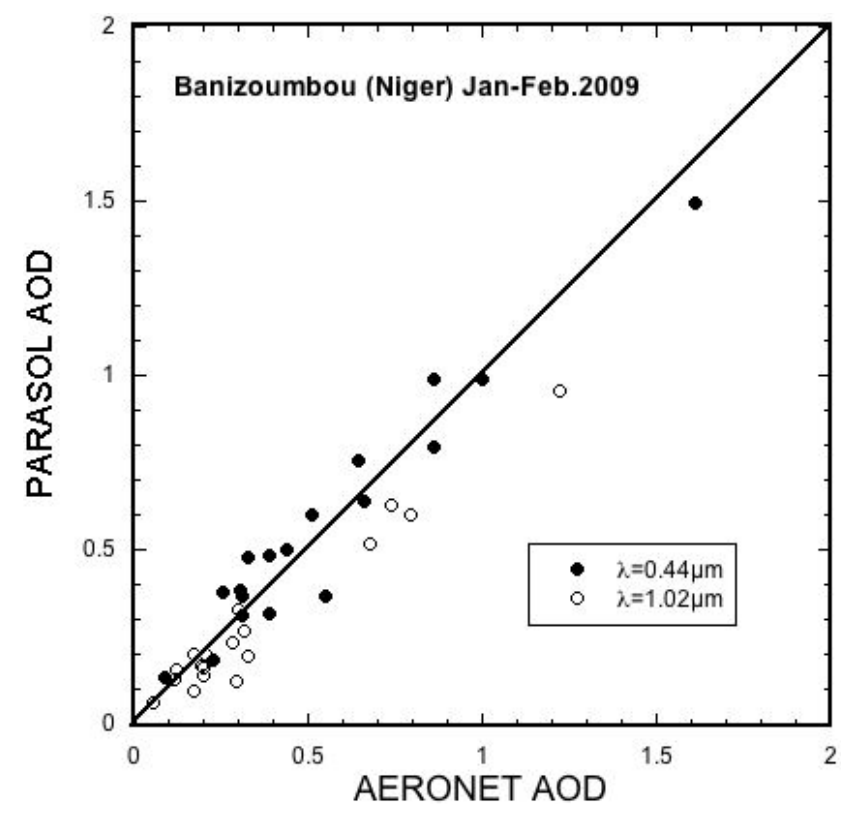

Fig. 4. Scatter plot of the AOD retrieved at 0.440 and $1.020 \mu \mathrm{m}$ from POLDER/PARASOL in January-February 2009 over Banizoumbou/Niger with the corresponding values provided by AERONET.

for errors in the input data, inverting multi-source data with different levels of accuracy, accounting for a priori and ancilliary information, estimating retrieval errors, clarifying potential of employing different mathematical inverse operations (e.g. comparing iterative versus matrix inversion), accelerating iterative convergence, etc. The algorithm includes additionally constraints on the retrieved surface properties, e.g. a priori constraints on the spectral variability of the parameters describing surface reflection and simultaneously retrieves the surface reflectance together with aerosol properties.

The capability is illustrated in Fig. 4. It shows a preliminary comparison of AODs retrieved at 440 and $1020 \mathrm{~nm}$ from PARASOL with coincident AERONET measurements over Banizoumbou, Niger, in January-February 2009. The inversion is not perfect but is shown very promising since the retrieval of AOD over bright surfaces like deserts is the most challenging objective. Additional sensitivity studies are under progress but improvement of the speed of the inversion by a factor $50-100$ is still required for applying the method operationnally to the PARASOL archive.

\subsection{Aerosols above a cloud deck}

The A-Train concept is to combine the information from several sources for giving a more complete answer than it would be possible from any single satellite (http://aqua.nasa. gov/doc/pubs/A-Train_Fact_sheet.pdf). The detection of an aerosol layer above a cloud is a great illustration of the concept. It's the differences between the cloud top pressures
(CTP) derived from three sensors, MODIS, PARASOL and CALIOP, that led us to develop a method for retrieving the AOD from the polarized radiances backscattered by a cloud deck.

PARASOL is providing two CTP's, a "Rayleigh CTP" based on the polarization due to the molecules that are above the cloud (Goloub et al., 1994) and a "O2 CTP" based on differential absorption measurements in two oxygen A-band at $760 \mathrm{~nm}$ (Vanbauce et al., 2003). MODIS measurements provide a third "IR CTP" in the thermal infrared channels (Menzel et al., 2008). Discrepancies among the three CTPs are anticipated since the retrievals are based on different physical processes that are not exactly sensitive to the same altitude range. More surprizing was the behavior of the "Rayleigh CTP" over some regions: it was smaller than the two others, which was not anticipated and in conflict with our expectations. The corresponding areas were located in regions and time associated with the presence of aerosols in the fine mode, i.e. pollution and/or smoke generated mainly by anthropogenic activities. Waquet et al. (2009) have identified several cases over the subtropical South Atlantic ocean in August-September when fires occur in South-West Africa and when meteorological processes favor biomass burning aerosols transport to the West. The excess of polarization within the $90^{\circ}-120^{\circ}$ scattering angle range due to the presence of an aerosol plume above the cloud lead in fact the "Rayleigh" algorithm to underestimate the CTP, as confirmed by CALIOP observations. Since dust do not polarize radiation like aerosols within the fine mode, the method cannot handled it with a similar approach but alternative solution using the polarized rainbow is under consideration (Waquet el al., 2010).

\section{Conclusions}

The A-Train with five satellites (AQUA, AURA, CALIPSO, CLOUDSAT, PARASOL) and more than four years of coincident data offers an unique archive for improving our knowledge of the optical, physical and radiative properties of clouds and aerosols. Although each mission of the A-Train is fully autonomous and consistent by itself, their combination provides the opportunity to derive, to compare, to validate new parameters as well as to put additional constraints on inversion scheme.

PARASOL data inversions provide aerosol and cloud parameters needed for analyzing the corresponding complex radiative effects. Concerning aerosol, data collected over ocean allow to separate the fine aerosol component due to anthropogenic activities from the coarse mode resulting from natural processes. Moreover, when the scattering angle range is large enough $\left(90^{\circ}-160^{\circ}\right)$, PARASOL can discriminate large spherical marine aerosols from non-spherical desert aerosols, retrieve the effective radius of the accumulation and coarse modes and evaluate the real part of the refractive index. Over 
land surfaces that are highly reflective, PARASOL is using the polarized radiance to reduce the surface contribution. Since polarization is mainly sensitive to the presence of small particles, it allows us to derive the optical depth of the fine mode only. The location, the strengths, the seasonal variability of the aerosol sources can be then monitored at a global scale.

Recent and future developments are even more appealing. With new algorithms presently under development, parameters such as the aerosol single scattering albedo, a key parameter for the semi-direct effect, will be retrieved. Current aerosol retrievals from passive sensors are limited over cloud-free pixels, which can bias the estimate of aerosol direct effect as well as the retrieval of cloud properties from satellite. With PARASOL, it is possible to quantify the direct effect of aerosols also above clouds and to provide the direct forcing at the top and bottom of the atmosphere at a global scale.

\section{Appendix A}

\section{Description of the PARASOL aerosol models}

We assume that the size distribution has two modes, fine and coarse, each of them follows a lognormal law defined by Eq. (A1)

$n(r)=\frac{d N}{d r}=\frac{n_{0}}{\sigma_{0} r_{0} \sqrt{2 \pi}} \exp \left[-\frac{\left(\ln r-\ln r_{0}\right)^{2}}{2 \sigma_{0}^{2}}\right]$

where $n_{0}$ is the density number, $r_{0}$ the median (or modal) radius and $\sigma_{0}$ the standard deviation of $\ln r$. The effective radius is defined by Eq. (A2).

$r_{\mathrm{eff}}=\int_{0}^{\infty} r^{3} n(r) d r / \int_{0}^{\infty} r^{2} n(r) d r=r_{0} \exp \left(2.5 \sigma_{0}^{2}\right)$

The parameters of the log-normal size distribution as well as the values of the refractive index used to build the LUT are reported in Tables A1 and A2 for ocean and land retrieval respectively.
Table A1. Size distribution parameters of the aerosol models over ocean. $m_{\mathrm{r}}$ and $m_{\mathrm{i}}$ are the real and imaginary parts of the refractive index. For the non-spherical mode, the phase matrix is directly obtained from Volten et al. (2001); the size parameters $r_{0}$ and $\sigma_{0}$ are assumed equal to the values of the spherical coarse mode; no values are assigned for the refractive index. The non-spherical fraction within the coarse mode is set to 5 discrete values: $0.00,0.25,0.50$, 0.75 and 1.00 .

\begin{tabular}{llcllr}
\hline & $r_{0}(\mu \mathrm{m})$ & $\sigma_{0}$ & $r_{\mathrm{eff}}(\mu \mathrm{m})$ & $m_{\mathrm{r}}$ & $m_{\mathrm{i}}$ \\
\hline Fine Mode & $0.04,0.08$, & 0.46 & $0.068,0.136$, & $1.35,1.45$, & 0.00 \\
& $0.10,0.13$ & & $0.169,0.220$ & 1.60 & \\
\hline $\begin{array}{l}\text { Spherical Coarse } \\
\text { Mode }\end{array}$ & 0.75 & 0.69 & 2.55 & $\begin{array}{l}1.33,1.35, \\
1.37\end{array}$ & 0.00 \\
\hline $\begin{array}{l}\text { Non-Spherical } \\
\text { Coarse Mode }\end{array}$ & 0.75 & 0.69 & 2.55 & n.d. & n.d. \\
\hline
\end{tabular}

$*$ n.d. $=$ Not Defined.

Table A2. Size distribution parameters of the aerosol models over land. $m_{\mathrm{r}}$ and $m_{\mathrm{i}}$ are the real and imaginary parts of the refractive index. Particles within the coarse mode are not considered in the computations of the LUT.

\begin{tabular}{llllll}
\hline & $r_{0}(\mu \mathrm{m})$ & $\sigma_{0}$ & $r_{\mathrm{eff}}(\mu \mathrm{m})$ & $m_{\mathrm{r}}$ & $m_{\mathrm{i}}$ \\
\hline & $0.05,0.06$, & & $0.075,0.090$, & & \\
& $0.07,0.08$, & & $0.105,0.120$, & & \\
Fine Mode & $0.09,0.10$, & 0.40 & $0.135,0.150$, & 1.47 & 0.01 \\
& $0.11,0.12$, & & $0.165,0.180$, & & \\
& $0.13,0.15$ & & $0.195,0.225$ & & \\
\hline Spherical & n.d. & n.d. & n.d. & n.d. & n.d. \\
$\begin{array}{lllll}\text { Coarse } \\
\text { Mode }\end{array}$ & & & & & \\
\hline $\begin{array}{l}\text { Non-Spherical } \\
\text { Coarse }\end{array}$ & n.d. & n.d. & n.d. & n.d. & n.d. \\
Mode & & & & & \\
\hline
\end{tabular}

Acknowledgements. PARASOL is the second microsatellite in the Myriade series developed by the French Space Agency (CNES). The authors thank all those who have contributed to the development and operation of the satellite and ground segment. The authors are also thankful to CNRS-INSU, CNES/DSP, University Lille 1 and Région Nord-Pas de Calais for their support. Alexander Kokhanovsky is acknowledged for his assistance throughout the review process. The PARASOL level 1 data are available from http://polder.cnes.fr/. PARASOL level-2 and Level-3 products, browse images as well as data from some other A-Train sensors are available from the ICARE data center (http://www.icare.univ-lille1.fr/parasol/). The authors thank the ICARE Data and Services Center for its assistance and development support.

Edited by: A. Kokhanovsky 


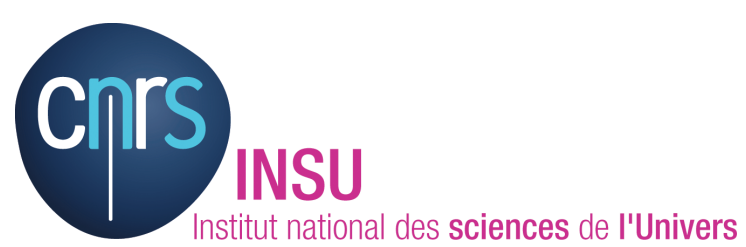

The publication of this article is financed by CNRS-INSU.

\section{References}

Anderson, T. L., Charlson, R. J., Bellouin, N., Boucher, O., Chin, M., Christopher, S. A., Haywood, J., Kaufman, Y., Kinne, S., Ogren, J. A., Remer, L. A., Takemura, T., Tanré, D., Torres, O., Trepte, C. R., Wielicki, B., A., Winker, D. M., and Yu, H.: An "A-Train" Strategy for Quantifying Direct Climate Forcing by Aerosols, B. Am. Meteorol. Soc., 86, 1795-1809, 2005.

Bréon, F. M. and Colzy, S.: Cloud detection from the spaceborne POLDER instrument and validation against surface synoptic observations, J. Appl. Meteorol., 38, 777-785, 1999.

Bréon, F. M., Vermeulen, A., and Descloitres, J.: An evaluation of satellite aerosol products against sunphotometer measurements, Remote Sens. Environ., in press, 2011.

Carlson, T. N. and Prospero, J. M.: The large scale movement of Saharan air outbreaks over the Northern equatorial Atlantic, J. Appl. Meteorol., 11, 283-297, 1972.

Chamaillard, K., Jennings, S. G., Kleefeld, C., Ceburnis, D., and Yoon, Y.J.: Light backscattering and scattering by nonspherical sea-salt aerosols, J. Quant. Spectrosc. Ra., 79-80, 577-97, 2003.

Chin, M., Ginoux, P., Kinne, S., Torres, O., Holben, B. N., Duncan, B. N., Martin, R. V., Logan, J. A., Higurashi, A., and Nakajima, T.: Tropospheric aerosol optical thickness from the GOCART model and comparisons with satellite and sun photometer measurements, J. Atmos. Sci., 59, 461-483, 2002.

Chowdhary, J., Cairns, B., Mishchenko, M., and Travis, L.: Retrieval of aerosol properties over the ocean using multispectral and multiangle photopolarimetric measurements from the Research Scanning Polarimeter, Geophys. Res. Lett., 28, 243-246, 2001.

Cox, C. and Munk, W.: Measurement of the Roughness of the Sea Surface from Photographs of the Sun's Glitter, J. Opt. Soc. Am., 44, 838-850, 1954.

Deschamps, P. Y., Bréon, F. M., Leroy, M., Podaire, A., Sèze, G., and Bricaud, A.: The POLDER mission: Instrument characteristics and scientific objectives, IEEE T. Geosci. Remote, 32, 598615,1994

Deuzé, J. L., Bréon, F. M., Roujean, J. L., Deschamps, P. Y., Devaux, C., Herman, M. and Podaire, A.:Analysis of the POLDER (POLarization and Directionality of Earth's Reflectances) airborne instrument observations over land surfaces, Remote Sens. Environ., 45, 137-157, 1993.

Deuzé, J. L., Herman, M., Goloub, P., Tanré, D., and Marchand, A.: Characterization of aerosols over ocean from POLDER/ADEOS1, Geophys. Res. Lett., 26, 1421-1424, 1999.

Deuzé, J. L., Bréon, F. M., Devaux, C., Goloub, P., Herman, M., Lafrance, B., Maignan, F., Marchand, A., Nadal, F., Perry, G., and Tanré, D.: Remote sensing of aerosols over land surfaces from POLDER-ADEOS-1 polarized measurements, J. Geophys. Res., 106, 4913-4926, 2001.

Dollfus, A. and Coffeen, D. L., : Polarization of Venus. I. Disk observations, Astron. Astrophys., 8, 251-266, 1970.

Dubovik, O.: Optimization of Numerical Inversion in Photopolarimetric Remote Sensing, in: Photopolarimetry in Remote Sensing, edited by: Videen, G., Yatskiv, Y., and Mishchenko, M., Kluwer Academic Publishers, Dordrecht, The Netherlands, 65106, 2004.

Dubovik, O., Holben, B. N., Eck, T. F., Smirnov, A., Kaufman, Y. J., King, M. D., Tanré , D., and Slutsker, I.: Climatology of aerosol absorption and optical properties in key worldwide locations, J. Atmos. Sci. , 59, 590-608, 2002.

Dubovik, O., Lapyonok, T., Kaufman, Y. J., Chin, M., Ginoux, P., Kahn, R. A., and Sinyuk, A.: Retrieving global aerosol sources from satellites using inverse modeling, Atmos. Chem. Phys., 8, 209-250, doi:10.5194/acp-8-209-2008, 2008.

Dubovik, O., Herman, M., Holdak, A., Lapyonok, T., Tanré, D., Deuzé, J. L., Ducos, F., Sinyuk, A., and Lopatin, A.: Statistically optimized inversion algorithm for enhanced retrieval of aerosol properties from spectral multi-angle polarimetric satellite observations, Atmos. Meas. Tech., 4, 975-1018, doi:10.5194/amt-4975-2011, 2011

Fan, X., Goloub, Ph., Deuzé , J.-L., Chen, H., Zhang, W., Tanré , D., and Li, Z.: Evaluation of PARASOL aerosol retrieval over North East Asia, Remote Sens. Environ., 112, 697-707, 2008.

Fougnie, B. and Bach, R.: Monitoring of Radiometric Sensitivity Changes of Space Sensors Using Deep Convective Clouds: Operational Application to PARASOL, IEEE T. Geosci. Remote, 47, 851-861, 2009.

Fougnie, B., Bracco, G., Lafrance, B., Ruffel, C., Hagolle, O., and Tinel, C.: PARASOL in-flight calibration and performance, Appl. Opt., 46, 5435-5451, 2007.

Fraser, R. and Kaufman, Y.: The Relative Importance of Aerosol Scattering and Absorption in Remote Sensing, IEEE Transactions on Geoscience and Remote Sensing, GE-23, 625-633, doi:10.1109/TGRS.1985.289380, 1985.

GAW, Proceedings of WMO/GAW Experts Workshop on a Global Surface-based Network for Long Term Observations of Column Aerosol Optical Properties, Davos, Switzerland, 8-10 March 2004 GAW Report \#162 available at http://www.wmo.ch/web/ arep/gaw/gawreports.html, 2004.

Goloub, P., Deuzé, J.-L., Herman, M., and Fouquart, Y.: Analysis of the POLDER polarization measurements performed over cloud covers, IEEE T. Geosci. Remote, 32, 78-88, 1994.

Goloub, P., Tanré, D., Deuzé, J. L., Herman, M., Marchand, A., and Bréon, F. M.: Validation of the first algorithm applied for deriving the aerosol properties over the ocean using the POLDER/ADEOS measurements, IEEE T. Geosci. Remote, 37, 1586-1596, 1999.

Hagolle, O., Goloub, P., Deschamps, P. Y., Cosnefroy, H., Briottet, X., Bailleul, T., Nicolas, J.M., Parol, F., Lafrance, B., and Herman, M.: Results of POLDER in-flight calibration, IEEE T. Geosci. Remote, 37, 1550-1566, 1999.

Hansen, J. E. and Hovenier, J. W.: Interpretation of the polarization of Venus, J. Atmos. Sci., 31, 1137-1160, 1974.

Hansen, J., Sato, M., and Ruedy, R.: Radiative forcing and climate response, J. Geophys. Res., 102, 6831-6864, 1997.

Hasekamp, O. P.: Capability of multi-viewing-angle photo- 
polarimetric measurements for the simultaneous retrieval of aerosol and cloud properties, Atmos. Meas. Tech., 3, 839-851, doi:10.5194/amt-3-839-2010, 2010.

Herman M. and Vanderbilt, V.: Polarimetric observations in the solar spectrum for remote sensing purposes, Remote Sens. Rev., 15, 35-57, 1997.

Herman, M., Balois, J. Y., Gonzales, L., Lecomte, P., Lenoble, J., Santer, R. and Verwaerde, C.: Stratospheric aerosol observations from a balloon-borne polarimetric experiment, Appl. Opt., 25, 3573-3584, 1986.

Herman, J. R., Bhartia, P. K., Torres, O., Hsu, C., Seftor, C., and Celarier, E.: Global distribution of UV-absorbing aerosol from Nimbus-7/TOMS data, J. Geophys. Res., 102, 16911-16922, 1997a.

Herman, M., Deuzé, J. L., Devaux, C., Goloub, P., Bréon, F. M., and Tanré, D.: Remote Sensin of Aerosols over Land Surfaces Including Polarization Measurements: Applications to POLDER Measurements, J. Geophys. Res., 102, 17039-17050, 1997b.

Herman, M., Deuzé, J. L., Marchand, A., Roger, B., and Lallart, P.: Aerosol Remote Sensing from POLDER/ADEOS over the Ocean. Improved Retrieval using Non-Spherical Particle Model, J. Geophys. Res., 110, D10S02, doi:10.1029/2004JD004798, 2005.

Holben, B. N., Eck, T. F., Slutsker, I., Tanré, D., Buis, J. P., Setzer, A., Vermote, E., Reagan, J. A., Kaufman, Y. J., Nakajima, T., Lavenu, F., Jankowiak, I., and Smirnov, A.: AERONET - A federated instrument network and data archive for aerosol characterization, Remote Sens. Environ., 66, 1-16, 1998.

Holben, B. N., Tanré, D., Smirnov, A., Eck, T. F., Slutsker, I., Abuhassan, N., Newcomb, W. W., Schafer, J. S., Chatenet, B., Lavenu, F., Kaufman, Y. J., Castle, J. V., Setzer, A., Markham, B., Clark, D., Frouin, R., Halthore, R., Karneli, A., O’Neill, N. T., Pietras, C., Pinker, R. T.,Voss, K., and Zibordi, G.: An emerging ground-based aerosol climatology: Aerosol optical depth from AERONET, J. Geophys. Res., 106, 12067-12097, 2001.

Hsu, N. C., Tsay, S.-C., King, M. D., and Herman, J. R.: Deep blue retrievals of Asian aerosol properties during ACE-Asia, IEEE T. Geosci. Remote, 44, 3180-3195, 2006.

Husar, R. B., Prospero, J., and Stowe, L. L.: Characterization of tropospheric aerosols over the oceans with the NOAA AVHRR optical thickness operational product, J. Geophys. Res., 102, 1688916909, 1997.

Kahn, R. A., Banerjee, P., and McDonald, D.: The sensitivity of multiangle imaging to natural mixtures of aerosols over ocean, J. Geophys. Res., 106, 18219-18238, 2001.

Kaufman, Y. J., Tanré, D., Remer, L., Vermote, E., Chu, A., and Holben, B.: Operational remote sensing of tropospheric aerosol over land from EOS moderate resolution imaging spectroradiometer, J. Geophys. Res., 102, 17051-17067, 1997.

Kaufman, Y. J., Tanré, D., and Boucher, O.: A satellite view of aerosols in the climate system, Nature, 419, 215-223, 2002.

Kaufman, Y. J., Koren, I., Remer, L. A., Tanré, D., Ginoux, P., and Fan, S.: Dust transport and deposition observed from the Terra-Moderate Resolution Imaging Spectroradiometer (MODIS) spacecraft over the Atlantic Ocean, J. Geophys. Res., 110, D10S12, doi:10.1029/2003JD004436, 2005.

King, M., Kaufman, Y., Menzel, P., and Tanré, D.: Remote sensing of Cloud, Aerosol and Water Vapor properties from the Moderate Resolution Imaging Spectrometer (MODIS), IEEE T. Geosci.
Remote, 30, 2-27, 1992.

Koepke, P.: Effective reflectance of the oceanic whitecaps, Appl. Opt., 23, 1816-1824, 1984.

Kokhanovsky, A. A., Deuzé, J. L., Diner, D. J., Dubovik, O., Ducos, F., Emde, C., Garay, M. J., Grainger, R. G., Heckel, A., Herman, M., Katsev, I. L., Keller, J., Levy, R., North, P. R. J., Prikhach, A. S., Rozanov, V. V., Sayer, A. M., Ota, Y., Tanré, D., Thomas, G. E., and Zege, E. P.: The inter-comparison of major satellite aerosol retrieval algorithms using simulated intensity and polarization characteristics of reflected light, Atmos. Meas. Tech., 3, 909-932, doi:10.5194/amt-3-909-2010, 2010.

Lenoble, J., Herman, M., Deuzé , J. L., Lafrance, B., Santer, R., and Tanré, D.: A Successive Order of Scattering Code for Solving the Vector Equation of Transfer in the Earth's Atmosphere with Aerosols, J. Quant. Spectrosc. Ra., 107, 479-507, 2007.

Maignan, F., Bréon, F.-M., Féd‘ ele, E., and Bouvier, M.: Polarized reflectances of natural surfaces: Spaceborne measurements and analytical modeling, Remote Sens. Environ., 113, 2642-2650, 2009.

Menon, S., DelGenio, A. D., Koch, D., and Tselioudis, G.: GCM Simulations of the Aerosol Indirect Eff ect: Sensitivity to Cloud Parameterization and Aerosol Burden, J. Atmos. Sci., 59, 692713, 2002.

Menzel, W. P., Frey, R. A., Zhang, H., Wylie, D. P., Moeller, C. C., Holz, R. E., Maddux, B., Baum, B. A., Strabala, K. I., and Gumley, L. E.: MODIS global cloud-top pressure and amount estimation: Algorithm description and results, J. Appl. Meteorol. Clim., 47, 1175-1198, 2008.

Middleton, N. J.: Dust storms in the Mongolian People's Republic, J. Arid Environ., 20, 287-297, 1991.

Mishchenko, M. I. and Travis, L. D.: Satellite retrieval of aerosol properties over the ocean using polarization as well as intensity of reflected sunlight, J. Geophys. Res., 102, 16989-17013, 1997.

Mishchenko, M. I., Cairns, B., Kopp, G., Schueler, C. F., Fafaul, B. A., Hansen, J. E., Hooker, R.J., Itchkawich, T., Maring, H. B., and Travis, L. D.: Accurate monitoring of terrestrial aerosols and total solar irradiance: Introducing the Glory Mission, B. Am. Meteorol. Soc., 88, 677-691, doi:10.1175/BAMS88-5-677, 2007.

Nadal, F. and Bréon, F. M.: Parameterization of surface polarized reflectance derived from POLDER spaceborne measurements, IEEE T. Geosci. Remote, 37, 1709-1718, 1999.

Omar, A. H., Won, J.-G., Winker, D. M., Yoon, S.-C., Dubovik, O., and McCormick, M. P.: Development of global aerosol models using cluster analysis of Aerosol Robotic Network (AERONET) measurements, J. Geophys. Res., 110, D10S14, doi:10.1029/2004JD004874, 2005.

Parkinson, C. L., Aqua: an Earth-Observing Satellite mission to examine water and other climate variables, IEEE T. Geosci. Remote, 41, 173-183, 2003.

Prospero, J. M., Ginoux, P., Torres, O., Nicholson, S. E., and Gill, T. E.: Environmental characterization of global sources of atmospheric soil dust identified with the Nimbus 7 Total Ozone Mapping Spectrometer (TOMS) absorbing aerosol product, 40, 1002, doi:10.1029/2000RG000095, 2002.

Ramanathan, V., Crutzen, P., Kiehl, J., and Rosenfeld, D.: Aerosols, Climate, and the Hydrological Cycle, Science, 294, 2119-2124, 2001.

Remer, L. A., Kaurman, Y. J., Tanré, D., Mattoo, S., Chu, D. A., 
Martins, J. V., Li, R.-R., Ichoku, C., Levy, R. C., Kleidman, R. G., Eck, T. F., Vermote, E., and Holben, B.N.: The MODIS aerosol algorithm, products, and validation, J. Atmos. Sci., 62, 947-973, 2005.

Remer, L. A., Kleidman, R. G., Levy, R. C., Tanré, D., Mattoo, S., Vanderlei Martins, J., Ichoku, Ch., Koren, I., Yu, H., and Holben, B. N.: An emerging global aerosol climatology from the MODIS satellite sensors, J. Geophys. Res., 113, D14S07, doi:10.1029/2007JD009661, 2008.

Santer, R. and Herman, M.: Wavelength dependence of polarization. XXXVIII - Analysis of ground-based observations of Venus, The Astronomical Journal, 84, 1802-1810, 1979.

Tanré , D., Kaufman, Y. J., Herman, M., and Mattoo, S.: Remote sensing of aerosol over oceans from EOS-MODIS, J. Geophys. Res., 102, 16971-16988, 1997.

Torres, O., Chen, Z., Jethva, H., Ahn, C., Freitas, S. R., and Bhartia, P. K.: OMI and MODIS observations of the anomalous 20082009 Southern Hemisphere biomass burning seasons, Atmos. Chem. Phys., 10, 3505-3513, doi:10.5194/acp-10-35052010, 2010.

Vanbauce, C., Cadet, B., and Marchand, R. T.: Comparison of POLDER apparent and corrected oxygen pressure to ARM/MMCR cloud boundary pressures, Geophys. Res. Lett., 30, 1212, doi:10.1029/2002GL016449, 2003.

Vaughan, M. A., Powell, K. A., Kuehn, R. E., Young, S. A., Winker, D. M., Hostetler, C. A., Hunt, W. H., Liu, Z., McGill, M. J., and Getzewich, B. J.: Fully Automated Detection of Cloud and Aerosol Layers in the CALIPSO Lidar Measurements, J. Atmos. Ocean. Tech., 26, 2034-2050, 2009.

Volten, H., Munoz, O., Rol, E., de Haan, J. F., Vassen, W., and Hovenier, J. W.: Scattering matrices of mineral aerosol particles at $441.6 \mathrm{~nm}$ and $632.8 \mathrm{~nm}$, J. Geophys. Res., 106, 17375-17401, 2001.

Wang, M. and Gordon, H. R.: Radiance reflected from the oceanatmosphere system: Synthesis from individual components of the aerosols size distribution, Appl. Opt., 33, 7088-7095, 1994.
Waquet, F., Riedi, J., Labonnote, L., Goloub, P., Cairns, B., Deuzé, J.-L., and Tanré, D.: Aerosol remote sensing over clouds using the A-Train observations, J. Atmos. Sci., 66(8), 2468-2480, 2009.

Waquet, F., Riedi, J., Labonnotte, L., Thieuleux, F., Ducos, F., Goloub, Ph., and Tanré, D.: Aerosols remote sensing over clouds using the A-train observations, A-Train Symposium, New Orleans, USA, 25-28 October, 2010.

Washington, R., Todd, M., Middleton, N. J. and Goudie, A. S.: Dust-Storm Source Areas Determined by the Total Ozone Monitoring Spectrometer and Surface Observations, Annals of the Association of American Geographers, 93(2), 297-313, 2003.

Winker, D. M., Pelon, J., and McCormick, M. P.: The CALIPSO mission: Spaceborne lidar for observation of aerosols and clouds, in: Lidar Remote Sensing for Industry and Environment Monitoring III, Proc. SPIE vol. 4893, edited by: Singh, U. N., Itabe, T., and Lui, Z., SPIE, Bellingham, WA, 1-11, 2003.

Winker, D. M., Vaughan, M. A., Omar, A., Hu, Y., Powell, K. A., Liu, Z., Hunt, W. H., and Young, V.: Overview of the CALIPSO mission and CALIOP data processing algorithms, J. Atmos. Ocean. Tech., 26, 2310-2323, 2009.

Winker, D. M., Pelon, J., Coakley Jr., J. A., Ackerman, S. A., Charlson, R. J., Colarco, P.R., Flamant, P., Fu, Q., Hoff, R. M., Kittaka, C., Kubar, T. L., LeTreut, H., McCormick, M. P., Mégie, G., Poole, L., Powell, K., Trepte, C., Vaughan, M. A., and Wielicki, B. A.: The CALIPSO mission: a global 3D view of aerosols and clouds, B. Am. Meteorol. Soc., 91, 1211-1229, doi:10.1175/2010BAMS3009.1, 2010.

WMO, Radiation and Climate. Workshop on Implementation of the Baseline Surface Radiation Network. (Washington, DC, U.S.A., 3-5 December 1990), WCRP-54, report no. 406, World Meteorological Organization, Geneva, 1991.

Yu, H., Remer, L. A. , Chin, M., Bian, H., Kleidman, R. G. and Diehl, T.: A satellitebased assessment of transpacific transport of pollution aerosol, J. Geophys. Res., 113, D14S12, doi:10.1029/2007JD009349, 2008. 